\title{
A survey on the effects of the exchange rate changes and financial flexibility on the usage of financial leverage in accepted companies of Tehran stock exchange
}

\author{
Hamid Mahmoodabadi $^{\text {aa }}$, Hoda Kiafar ${ }^{\mathrm{b}}$, Reza Zare ${ }^{\mathrm{c}}$, Moslem Gheisari ${ }^{\mathrm{d}}$ \\ ${ }^{a}$ Assistant Professor, Shiraz University,Shiraz, Iran \\ ${ }^{b}$ Accounting Department, Lar Branch, Lar Usage Scientific General University, Marvdasht, Iran \\ c Accounting Department, Marvdasht Branch, Islamic Azad University, Marvdasht, Iran \\ ${ }^{d}$ Accounting Department, Yasouge Branch, Islamic Azad University, Yasouge, Iran
}

\begin{abstract}
In the present study we try to examine the exchange rate changes and financial flexibility as the economic stable indexes on the financial leverage use in the companies so the main issue in this study is to define the financial leverage relation with exchange rate changes and financial flexibility. That is why 88 companies of the companies listed in Tehran stock exchange in 2005-2011. The study type is descriptive-correlative and the multivariable linear regression was used to analyze the data. The findings from the hypotheses test state there is a significant relation between financial leverage and financial flexibility while there isn't relation between financial leverage and exchange rate changes.
\end{abstract}

Key Words: Growth opportunities, Exchange rate changes, Financial flexibility, financial leverage.

\section{(C) 2013 Published by SSBFNET}

\section{Introduction}

The specialist and academic researchers have been interested too much in the examination of economic stable effect on financial leverage. Finance through debt is one of the important factors in investment decisions in the level of micro- and macroeconomics. As an important factor and effective on the economic growth is successful when the estimated macroeconomic are founded in an atmosphere of trust and stability. So one of the government policies is to create trust and stability regarding future.

Companies' capital structure is accumulated from the owners' rights to benefit from their future benefits and finance sources including long-term debts, ordinary and preferred shares and profit. Company's capital structure is made of debt (loan) and owners' equity (shares) (Drobetz and Fix, 2003).

So the most important issue the directors of all companies encountered with is to define the rate of the company's debt by virtue of the economic stability indexes. Here it is possible to consider the capital structure as a representative for financial leverage and the exchange rate changes and financial flexibility as the economic stable indexes.

This study is to examine the effect of economic stable on the financial leverage use in the companies listed in Tehran stock exchange.

${ }^{a}$ Corresponding author: Email: Hamid_Mahmoodabadi@yahoo.com 


\section{Literature Review}

2.1.Economic stable

In economic literature the economic stable discussion has been an important issue for the macroeconomic studies and researches since several decades. As one of the biggest units to create policies in the developing and even developed countries the government plays an important role in the economic orientation. In view of World Bank the economic stable appears when, "The inflation is controlled, it is possible to repay the internal and external debts and the economic crises (If any) may be solved in 2-3 years" (World Development Report, 1991). Here two factors, growth opportunities and official inflation expectation are used to define the economic stable.

In recent years economic security and political freedom have been focused. A safe economic environment is an important factor for private investments and economic growth in developing countries. Many companies benefit from complementary policies to adjust and modify the economic structure so they create internal and external equilibrium in economy simultaneously (Hol \& Wijst, 2008).

Fischer was one of them who found the importance of macroeconomics stable. His study findings confirmed strongly the positive effect of the macroeconomics stable on growth. Also they show that inflation decreases economic growth by decreasing investment and interest. New theoretical and experimental studies show that the financial markets play important role in economic growth. The efficient financial system transfer the capital from the depositors to the borrowers and guide the sources towards the productive and profitable investing projects. If the investment interest is more, the economic growth is more, too (King \& Levine, 1993).

In recent years specially after Second World War many policy makers and economists have been interested in inflation and economic growth in a way that their compatibility or incompatibility in company capital structure have been examined in a large amount of the economic literature (Hol \& Wijest, 2008). So the inflation rate and economic growth opportunities define the economics stable in developing countries.

\subsection{Exchange rate changes}

The economic and financial sector has been interested in exchange rate as a macroeconomic factor. In fact, the rate indicates the state economic condition and is a factor to compare the state economy with other countries'. The rate is the currency of a country in comparison with other country's. The exchange rate is important because it influences the price of internal and external goods. When the state currency value increases the goods produced by the country becomes more expensive in abroad and the internal producers cannot sell easily their goods in abroad. Also the foreign goods will become cheaper in the country and foreign goods producers compete with each other to sell more their goods. On the contrary, when the state currency value decreases the goods of the country become cheaper in abroad and the foreign goods become more expensive in the country. Generally the exchange rate changes may influence the companies benefiting from foreign credits because the financial sources which entered into the company in this way should change to state currency. So the state currency value increase in contrast to other countries' exchange may lead the company to gain more financial sources. Also on the other hand, the exchange rate increase and state currency value decrease lead the cash money to exit more and company interest cost increases, too so the ratio of the debts to the special value increases; meanwhile, the company should benefit from more debts. On this basis, there is a significant relation between the exchange rate changes and capital structure (Fanelli and Keifman, 2002).

\subsection{Financial flexibility}

RECENT SURVEYS OF AMERICAN AND EUROPEAN CFOS suggest that the most important driver of firms' capital structure decisions is the desire to attain and preserve financial flexibility. Financial flexibility represents the ability of a firm to access and restructure its financing at a low cost. Financially flexible firms are able to avoid financial distress in the face of negative shocks, and to readily fund investment when profitable opportunities arise. While a firm's financial flexibility depends on external financing costs that may reflect firm characteristics such as size, it is also a result of strategic decisions made by the firm related to capital structure, liquidity, and investment (Gamba and Triantis, 2008).

\subsection{Financial leverage}

Financial leverage is a percent of cash money financed by the creditors. Some expressions are used in accounting and financial affairs such as assets or amounts with stable cost creating yield for the company owners. Financial leverage is a device to define the company inefficiency to pay its debt. High debt of a company indicates high probable company inability to execute its undertakings (Brounen et al., 2006).

Financing by debt is named 'financial leverage' in the company capital structure. Debt as one of the most important external financial sources is interested by directors because of its tax advantages. The directors always 
equilibrate the shareholders' interests and profitable investment opportunities to be able to finance their investment opportunities with the least cost and by maximizing the company value (Hussey, 1999).

The company capital may be defined in long-term operation to finance as follows:

-By debt creation or share issue which refer to long-term or permanent finance arrangements in this capital context. So the capital debt, long-term company borrowing and capital holders' rights are long-term amounts provided by the company shareholders and owners. Financing by debt creation and borrowing is known as 'financial leverage'. Hence, financial leverage is a criterion of capital structure. In this section first we state the leverage and then analyze the capital structure (Brounen et al., 2006).

In financial management the leverage expression is used to describe the way by which the company owners may use financing by debt as the assets and company profit leverage. Finance by debt is one of the important factors in investment decision in micro- and macro-level. Debt use enable the owners to control more vast assets range and gain more profit and also makes possible to use the borrowing which is 'financial leverage' instead of benefiting from internal sources during investment time (McMenamine, 1999).

\subsection{Capital structure}

The capital structure issue was proposed for the first time by Modiliani and Miller (1960). The capital structure and its effect on financial and nonfinancial activities of the trading unit have been interested by many researchers since a long ago in a way that Rose et al. (2002) consider the rate and grade of the financial leverage as one of the most important financial directors' duties. It is attempted to define the composition of different financial sources to finance necessary activities and investments in examining the capital structure of the companies (Brounen et al., 2006).

Different meanings have been proposed for capital structure and each one states one aspect of finance ways as the capital structure.

-Cooper (1983) describes 'capital structure' as the ratio of the older long tap to total related investments.

-Hussey (1999) considers 'capital structure' as the equilibrium between debts and assets, company assets nature and borrowing composition. Also he says that the assets may be tangible, un tangible, current or long-term (Debt or share securities) and borrowing may be long-or short-term, fixed or floating, without or with risk. In ideal conditions the assets and debts should be adapted.

Belkoei(1999) introduces 'capital structure' the general claim to the company assets. He considers it including public issued securities, private investment, bank debt, commercial debt, rent contracts, tax debt, retirement salaries debts, delayed reward for management and personnel, good execution deposits, goods guarantees and other probable debts.

\section{The study history}

Byoun (2011) found that: developing firms that are in the phase of financial flexibility building have low leverage; growth firms that are in the phase of utilizing financial flexibility to fund growth opportunities have high leverage; finally, mature firms that are in the phase of recharging financial flexibility have moderate leverage. The financial flexibility framework provides explanations for several capital structure "puzzles" raised in the literature, suggesting that financial flexibility can be an important "missing link" in existing capital structure theories.

Gamba and Triantis (2008) showed that the value of financing flexibility depends on the costs of external financing, the level of corporate and personal tax rates that determine the effective cost of holding cash, the firm's growth potential and maturity, and the reversibility of capital. Through simulations, they demonstrated that firms facing financing frictions should simultaneously borrow and lend, and they examined the nature of dynamic debt and liquidity policies and the value associated with corporate liquidity.

Kuljot and Hodder (2000) address multinational capital structure decisions when firms have varying degrees of financial flexibility for shifting income and/or tax shields between subsidiaries. They found: (1) firms can use leverage to dramatically reduce negative valuation effects from operating in a high-tax country; (2) financial flexibility is a key determinant of optimal capital structure, acting as both a substitute and a complement for leverage; (3) multinational firms derive a synergistic effect from financial flexibility, which can enhance their value beyond that for a singlecountry firm from a low-tax jurisdiction; and (4) optimal capital structure typically differs substantially across subsidiaries, with each having positions in multiple currencies.

Fanelli and Keifman (2002) showed generally the exchange rate changes may influence the companies benefiting from foreign credits because the financial sources which entered into the company in this way should change to state currency. So the state currency value increase in contrast to other countries' exchange may lead the company to gain 
more financial sources. Also on the other hand, the exchange rate increase and state currency value decrease lead the cash money to exit more and company interest cost increases, too so the ratio of the debts to the special value increases; meanwhile, the company should benefit from more debts. On this basis, there is a significant relation between the exchange rate changes and capital structure.

Hass and Peeters (2006), examined the dynamic adjustment in line with the purposed capital structure for the companies in developing economies. The used internal static model adjusts well the purposed leverage. The data were used for ten countries with little economy in 1993-2001. They found that the companies increase their during change process and the difference between real and purposed leverages decreases. On one hand, the company profitability and life are factors effective in capital structure goals which have negative and positive relations with financial leverage, respectively.

In his article, 'Macroeconomic Factors Defining Capital Structure', Teker(2008) examined the effect of the factors defining macroeconomics of the companies. The study included 42 companies listed in Turkey stock exchange in 2000-2007. The defining factors included tangible assets, size, growth opportunities and profitability; each factor was calculated by periodic analysis for each company. The findings suggest that the assets yield rate and presenting them have positive effect on the financial leverage. On the other hand, the ratio of total amortization to total assets and the profit margin of the sale have negative and important relation with the financial leverage.

Having used the structural equation modeling approach Chang et al (2008) examined the factors effective on capital structure selection. They used the multiple indexes and goals model with proper indexes to analyze 13,887 samples of the companies in 1998-2003. The capital structure is considered as long-term and short-term debts and the ratio of the debt changeable to the market value of the owners' equity. The findings indicate that the long-term growth and debt are of the most important factors in the capital structure selection. Also the leverage increases with fixed assets, non-debt tax shield, growth opportunities and company size and decreases, if the fluctuations, publicity costs, study and development costs, profitability, product uniqueness and bankruptcy probability increase.

In his study, 'How To Approach Capital \& Capital Structure Of Companies' Shamshur (2010) examined the importance of the financial limits in the decisions concerning the capital structure of the company in the developing economies by internal approach regression with the attitude to separate the unknown samples in 1996-2000. He show that the difference in finance limits has a defined effect on the capital structure of the company. The factors effective on the capital structure in finance in limited and unlimited companies is different. Tangible assets is an important factor in the leverage of the limited companies. When the growth opportunities and expected inflation influence the leverage of unlimited companies in developed economies it may conclude that these companies adjust their capital structure in contrast to the changes in great economic conditions. Thus, the unlimited companies adjust their capital structures in line with the goal more rapidly.

In their study, 'A stubborn persistence: Is the stability of leverage ratios determined by the stability of the economy?'Hanousek \&Shamshure(2011) found that the choice of capital structure firms make is a fundamental issue in the financial literature.

So,the capital structure of firms remains almost unchanged during their lives. This stability of leverage ratios is mainly generated by an unobserved firm-specific effect that is liable for the majority of the variation in capital structure.They demonstrate that even substantial changes in the economic environment do not affect the stability of firms'leverage due to the presence of credit constraints. Financially unconstrained firms are more responsive to economic changes and adjust to the target substantially faster than constrained firms.

\section{Hypotheses Development and study method}

The study hypotheses are as follows:

$\mathrm{H} 1$ :There is a significant relation between financial leverage and economic stability.

H1-1:There is a significant relation between financial leverage and financial flexibility.

H1-2:There is a significant relation between financial leverage and the exchange rate changes.

The model used to define the relations between independent and dependent variables are as follows:

LEVit $=\alpha+\beta 1 F L X i t-1+\beta 2$ EXit $-1+\beta 3$ PROit $+\beta 4$ TAit $+\beta 5$ MAit $+\beta 7 F S i t+\beta 8$ IMLit + eit

The definition of the variables and how to calculate them:

Independent variable:

Financial leverage (LEV):

In this study the financial leverage is the ratio of debt to total debt and owners' equity and the debt is the trading creditors minus total debt (Hass \& Peeters, 2006).

Dependent variables:

Financial Flexibility (FLX): 
Young (2011) benefited from the ratio of the floating capital of the operational assets to sale in order to calculate the financial flexibility; in this study the ratio was used.

Exchange rate changes (EX):

In this study the changes average announced by Central Bank were used.

Control variables:

Firm Size (FS):

The total assets logarithm is used to calculate the variable (Delkore, 2007).

The tangible assets (TA) ratio:

TA is calculated by dividing TA by total assets (Lemmon et al., 2008).

PRO(Profitability):

The variable is calculated by dividing profit by total assets (Chang et al., 2008).

Current assets (MA) ratio:

This ratio is gained by dividing current assets by total assets (Hanousk \& Samshur, 2011).

IML (Industry Leverage Mean):

This variable is calculated by the mean debts in industry (Shamshur, 2010). In this study 88 companies from 20 industries were selected and the middle; leverage for each industry was calculated separately.

\section{Data Analysis}

Descriptive statistics of the study variables are presented in Table 1.

Table 1: Descriptive statistics of the study variables

\begin{tabular}{|c|c|c|c|c|c|}
\hline study variables & mean & middle & maximum & minimum & $\begin{array}{l}\text { standard } \\
\text { deviation }\end{array}$ \\
\hline $\begin{array}{l}\text { financial } \\
\text { leverage }\end{array}$ & 0.6552 & 0.6623 & 0.9804 & 0.1569 & 0.1574 \\
\hline $\begin{array}{l}\text { Financial } \\
\text { flexibility }\end{array}$ & 49.1 & 48.0 & 80.7 & 13.2 & 17.0 \\
\hline $\begin{array}{l}\text { Exchange rate } \\
\text { changes }\end{array}$ & 14.9286 & 12.4000 & 25.4000 & 10.4000 & 5.0025 \\
\hline profitability & 0.1145 & 0.0954 & 0.5708 & -0.3127 & 0.1247 \\
\hline $\begin{array}{l}\text { tangible assets } \\
\text { ratio }\end{array}$ & 0.2451 & 0.2154 & 0.8888 & 0.0000 & 0.1681 \\
\hline $\begin{array}{l}\text { current assets } \\
\text { ratio }\end{array}$ & 0.7550 & 0.7852 & 1.0000 & 0.1111 & 0.1681 \\
\hline company size & 5.7264 & 5.6739 & 8.5200 & 4.2549 & 0.6238 \\
\hline $\begin{array}{l}\text { industry } \\
\text { leverage mean }\end{array}$ & 0.6688 & 0.6855 & 0.9893 & 0.3058 & 0.1279 \\
\hline
\end{tabular}

By virtue of the unit root tests of Levin's, Lin's and Cho's type (2002), if the test statistic significance is less than 0.05 , the study variables are stable during the study; it does not mean that the mean and variance of the variables over time and the variables covariance between different years have been stable. In present study the stability of all variables were examined and the gained findings were shown in Table 2.

Table 2: Findings from the stability test of the study variables

\begin{tabular}{lll}
\hline study variables & Levin, Lin and Cho & \\
\cline { 2 - 3 } financial leverage & test statistic & significance \\
Financial flexibility & 10.5106 & 0.000 \\
Exchange rate changes & -31.6651 & 0.000 \\
profitability & -15.1894 & 0.000 \\
tangible assets ratio & -8.5182 & 0.000 \\
current assets ratio & -10.7190 & 0.000 \\
company size & -10.7375 & 0.000 \\
industry leverage mean & -31.9157 & 0.000 \\
\hline
\end{tabular}


As you see in Table 2 for all the study variables the significance rate is less than 0.05 in the Levin, Lin and Cho unit root test (2002) indicating the variables are stable. Thus, the examined companies have no structural changes and if these variables are used in the model, it does not lead to quasi-regression creation.

The findings from the study hypotheses test:

First the Limer's ' $F$ ' test is used to select one of the board and mixed data method in order to estimate the model. The board method is used, otherwise, the mixed one is used because the data have been accumulated on each other indifferently. In the Limer's test the zero hypothesis states the same width from the origins (Mixed data) and the contrast hypothesis indicates the width from the origins (Board data) is not the same. Table 3 shows the findings from the Limer's test.

Table 3: Findings from the Limer's test

\begin{tabular}{llll}
\hline test type & test statistic & freedom grade & significance \\
\hline ' $\mathrm{F}$ ' test & 1.6904 & $(87.432)$ & 0.0004 \\
\hline
\end{tabular}

As you see in the Table 3 the significance rate of the 'F' test is less than 0.05 indicating, if the board data method is used, it is better than the mixed one. Considering the zero hypothesis of the Limer's test has not been accepted (Board data method has been known as the reference), the question is proposed that in which frame of the fixed or random effects methods the examined model is estimable? So the Hussmann test was used in order to select one of the fixed or random effects. In the test the zero hypothesis is the independence (Lack of relation between) the disorder element relating to the width from the origin and the descriptive variables (Random effects method) while the contrast hypothesis indicates the correlation between the disorder element relating to the width from the origin and the descriptive variables. If the zero hypothesis is accepted, the random effects method is used, otherwise, the fixed one is used. Table 4 shows the fin dings from Hussmann Test.

Table 4: Findings from the Hussmann test

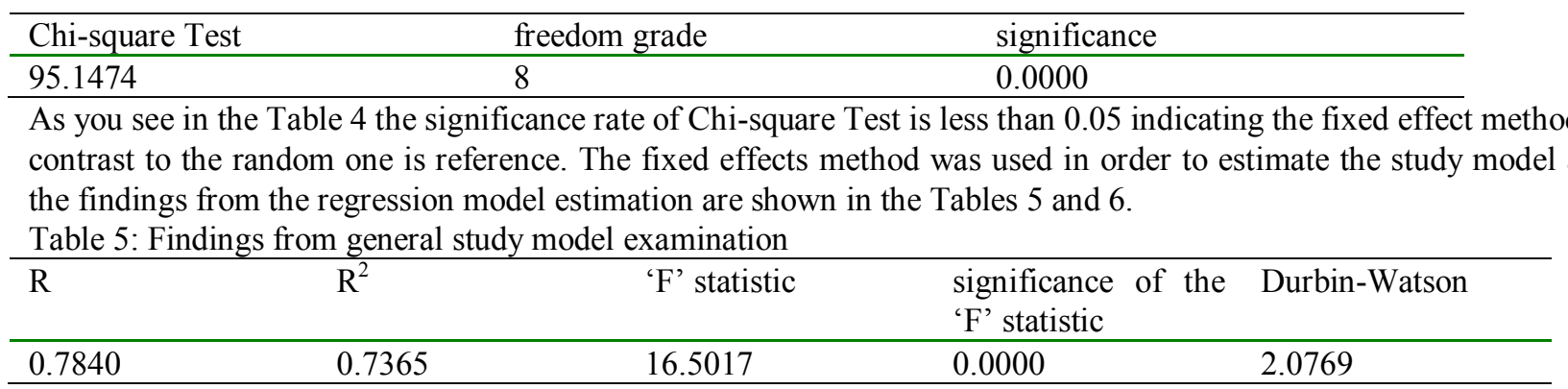

If there is no relation between the dependent, independent and control variables, all the independent variables coefficients should be zero in the equation. Hence, the significance of the regression equation should be tested and this is done by the ' $F$ ' statistic. As you see in Table 5 the ' $F$ ' statistic and the significance relating to this statistic indicates that the zero hypothesis namely the meaningless total model (All the coefficients are zero) is refused and the estimated regression model is significant in general. The definition coefficient $\left(\mathrm{R}^{2}\right)$ is the criterion describing the potency of the relation between the dependence, independence and control variables. In fact, the coefficient rate indicates how much percent of the dependence variable changes are described by the dependence and control variables. In this model the definition coefficient is 0.7840 namely 78.40 percent of the independence changes are explainable by the independence and control variables. 
Table 6: Findings from examining the study model partial coefficients

\begin{tabular}{|c|c|c|c|c|}
\hline variables & coefficients & standard error & statistic ' $\mathrm{T}$ ' & significance \\
\hline Financial flexibility & 0.0682 & 0.0203 & 3.3426 & 0.0002 \\
\hline $\begin{array}{l}\text { Exchange rate } \\
\text { changes }\end{array}$ & 0.0008 & 0.0012 & 1.689 & 0.0875 \\
\hline profitability & -0.3792 & 0.0584 & -6.4914 & 0.0000 \\
\hline tangible assets ratio & -0.9747 & 2.4865 & -0.3920 & 0.6952 \\
\hline current assets ratio & -0.9749 & 2.4862 & -0.3921 & 0.6951 \\
\hline company size & -0.0248 & 0.0330 & -0.7521 & 0.4524 \\
\hline $\begin{array}{l}\text { industry leverage } \\
\text { mean }\end{array}$ & 0.2739 & 0.0580 & 4.7253 & 0.0000 \\
\hline stable rate & 1.3242 & 2.4952 & 0.5307 & 0.5959 \\
\hline
\end{tabular}

By virtue of the numbers in above table and the significance of the variables it is possible to write the final equation as follows:

$L E V_{i t}=0.5307+3.3426 F L X_{i t-1}-6.4914 P R O_{i t}+4.7253 I M L_{i t}+\varepsilon_{i}$

The from examining the model variables coefficients are presented in Table 6. As you see the significance of statistic ' $\mathrm{T}$ ' of the independent variables indicates that the financial flexibility have a significant and positive effect on the financial leverage; however, exchange rate changes has no significant effect on the financial leverage. The examination of the significance relating to the statistic ' $\mathrm{T}$ ' of the control variables indicates that the profitability has significant and negative effect and the industry leverage have significant and positive effect on the financial leverage; however, the tangible assets ratio, current assets ratio and company size have no significant effect on the financial leverage.

\section{Conclusion}

The findings from the statistic tests indicate there is a significant relation between the financial flexibility and the on financial leverage. The relation between the financial flexibility and the financial leverage seem a logic relation and in previous studies by Hanisiok and Shemshore (2011) confirm the significant relation between the financial flexibility and the financial leverage. Shemshore believes that the difference in the finance limits has a defined effect on the company capital structure. The factors effective on the capital structure in the limited and unlimited companies are different in finance. When the financial flexibility factor influences the financial leverage rate of the unlimited companies in the finance it may conclude that these companies adjust their capital structure against actual changes in great economic conditions. Thus, the unlimited companies adjust more rapidly their capital structures in line with the goal. The significant relation between the financial flexibility and the financial leverage indicates that the companies listed in Tehran stock exchange will benefit favorably from the rapid economic changes in line with their growth.

The findings from the statistic tests indicate there isn't a significant relation between the foreign exchange changes and financial leverage. No significant relation between the foreign exchange changes and financial leverage indicates the companies listed in Tehran stock exchange operates weakly in confrontation with the foreign exchange changes and have not potency enough to change rapidly the capital structure in line with the goal.

\section{References}

Brounen, D., Jong. A. D., and Koedijk. K., (2006). Capital structure policies in Euroupe:Survey Evidence. Journal of Banking \& Finance, 30(5), PP.60-72.

Byoun, S., 2011. Financial Flexibility and Capital Structure Decision, Available at SSRN: http://ssrn.com/abstract=1108850 or http://dx.doi.org/10.2139/ssrn.1108850

Chang. C. C. Lee. A, F. Lee.C., (2008)."Determinants of capital structure choice:A structural equation modeling approach".The Quarterly of Economics and Finance, 49(2009),PP.197-213.

Cooper, W ,W .Kohler, S., (1983)." dictionary for accountants". Sixth edition. 
Delcoure. N. (2007). "The determinants of capital structure in transitional economies". Int, Rev, Econ, Finance, 16, PP. 400-415.

Drobetz, W. and Fix. R., (2003)."What are the determinants of the capital structure?Some evidence for Switzerland". working Paper No,4/30, Department of finance university of Basel, PP.500-512.

Durand, David., (1995)."Cost of Debt and Equity funds for Business; Trends and problems of measurement of corporate capital". PP. 91-116, Available at SSRN: http://www.ssrn.com.

Fanelli J. M. and Keifman, S. (2002). Finance and Changing Patterns in Developing Countries, Journal of Finance and Accounting, Vol. 15, No. 4, pp 143-171.

GAMBA, A., and TRIANTIS, A. (2008). The Value of Financial Flexibility. THE JOURNAL OF FINANCE.VOL. LXIII, NO. 5. pp. 2263-2296.

Haas, R. and Peeters, M., (2006). "The dynamic adjustment towards target capital structure of firms in transition economies". Econ, Transition 14, PP. 133-169.

Hanousk, J. and Shamshur, A., (2011). "A stubborn persistence: Is the stability of leverage ratios determined by the stability of the economy?". Journal of Corporate Finance, 17, PP.1360-1376.

Hol, S. and Wijst, V. N., (2008)."The financial structure of nonlisted firms". Appl, Finance Economic, 18, PP.559568.

Hussey, D., (1999). "Some thoughts on acquisition and merger". Japan Strategic Management Society. Vol 8, No.1, pp $51-60$.

King, R.G. and Levine, R., (1993). "Financial Intermediation and Economic Development". in

Kuljot, S., Hodder, J. E. (2000). Multinational capital structure and financial flexibility. Journal of International Money and Finance, 19, 853-884.

Lemmon, M. L., Roberts, M.R., Zender, J. F., (2008). "Back to the beginning: persistence and the cross-section of corporate capital structure". Journal of Finance, 63,PP. 1575-1608.

McMenamin, J., (1999)."Financial Management an introduction". PP.1-930.

Modigliani, F. Miller, H. (1985). The cost of capital, corporation finance and the theory of investment. American Economic Review, (3): 261-297.

Riahi Belkaui, A. (1999). Capital Structure-Determination, Evaluation and Accounting. First Edition, Quorum Books, London.

Shamshur. A., (2010). "Accesss to capital and capital structure of the firm". working paper series (ISSN 1211-3298).

Teker, D., (2008). "Macroeconomic Determinations of Capital structure for Turkish Firms:A panel Data Analysis". htt://bsy.marmara.edu.tr/konferanslar,2008,19.pdf.

World Bank. and World Development Report.,( 1991). PP.1-6 \& 155-157. 
Mahmoodabadi et al. /International Journal of Finance \& Banking Studies Vol 2, No 2, 2013 ISSN: 2147-4486 